\title{
A new bird record in China: Moustached Warbler (Acrocephalus melanopogon) and its song characteristics
}

\author{
XU Kangping ${ }^{1,2}$, NI Xin ${ }^{2}$, MA Ming ${ }^{2,3}$, CAI Xinbin', GOU Jun ${ }^{2}$, SUN Dahuan², LIN \\ Xuanlong ${ }^{1,2^{*}}$, DING Peng ${ }^{2,4^{*}}$ \\ ${ }^{1}$ Institute of Forest Ecology, Xinjiang Academy of Forestry, Urumqi 830063, China; \\ ${ }^{2}$ Xinjiang Bird Watching Society, Urumqi 830011, China; \\ ${ }^{3}$ Xinjiang Institute of Ecology and Geography, Chinese Academy of Sciences, Urumqi 830011, China; \\ ${ }^{4}$ Xinjiang Key Laboratory of Environmental Pollution Monitoring and Risk Warning, Xinjiang Academy of Environmental \\ Protection Science, Urumqi 830011, China
}

\begin{abstract}
Moustached Warbler (Acrocephalus melanopogon), belonging to the genus of Acrocephalus and the family of Acrocephalidae, breeds widely but locally in the warm temperate regions from Northwest Africa and eastern Iberian Peninsula to eastern Kazakhstan. However, this species has never been scientifically recorded in China. On 22 April 2016, a Moustached Warbler was observed in Ulanbuy wetland $\left(43^{\circ} 36^{\prime} \mathrm{N}\right.$, $87^{\circ} 43^{\prime} \mathrm{E} ; 1114 \mathrm{~m}$ a.s.1.), Urumqi, Xinjiang of China. This was the first photography-confirmed record of Moustached Warbler in China. As Moustached Warbler is a songbird, the songs were then recorded on 18 May 2016 using a Sony PCM D-100 recorder and the song characteristics were analyzed using Avisoft-SASLab software. The result showed that the mean maximum frequency of song strophes was $6.64( \pm 0.47) \mathrm{kHz}$ and the mean minimum frequency of song strophes was $1.72( \pm 0.14) \mathrm{kHz}$. This study could considered as a supplement of the checklist of birds in China.
\end{abstract}

Keywords: Moustached Warbler; Acrocephalus melanopogon; songbird; song characteristics; Urumqi; China

Citation: XU Kangping, NI Xin, MA Ming, CAI Xinbin, GOU Jun, SUN Dahuan, LIN Xuanlong, DING Peng. 2017. A new bird record in China: Moustached Warbler (Acrocephalus melanopogon) and its song characteristics. Journal of Arid Land, 9(2): 313-317. doi: 10.1007/s40333-017-0053-Z

\section{Background}

On 22 April 2016, XU Kangping and NI Xin observed and photographed a warbler (songbird) in Ulanbuy wetland $\left(43^{\circ} 36^{\prime} \mathrm{N}, 87^{\circ} 43^{\prime} \mathrm{E}\right.$; $1114 \mathrm{~m}$ a.s.l.), Urumqi, Xinjiang of China. The bird was finally identified as a Moustached Warbler (Acrocephalus melanopogon) by checking with experts at home and abroad as well as consulting the relevant references (e.g., Ali and Ripley 1997; Ayé et al., 2012). This was the first confirmed record of this species in China (Ma, 2011; Zheng, 2011; China Bird Report Eds, 2016). It should be added that as early as 1936, the trail of Moustached Warbler has been found in the East Tianshan Mountains, China (Sudilowskaja, 1936), but this information was not recognized by the scientific community due to lacks of photographs or specimens. So far, this species has not been confirmed included in the checklist of birds in

\footnotetext{
*Corresponding author: LIN Xuanlong (E-mail: xuanlonglin@163.com); DING Peng (E-mail: dpengde@126.com) Received 2016-07-25; revised 2016-10-06; accepted 2017-01-04

(C) Xinjiang Institute of Ecology and Geography, Chinese Academy of Sciences, Science Press and Springer-Verlag Berlin Heidelberg 2017
} 
China (China Bird Report Eds, 2016). Our finding formally confirmed the presence of this species in China through the photograph (Fig. 1).

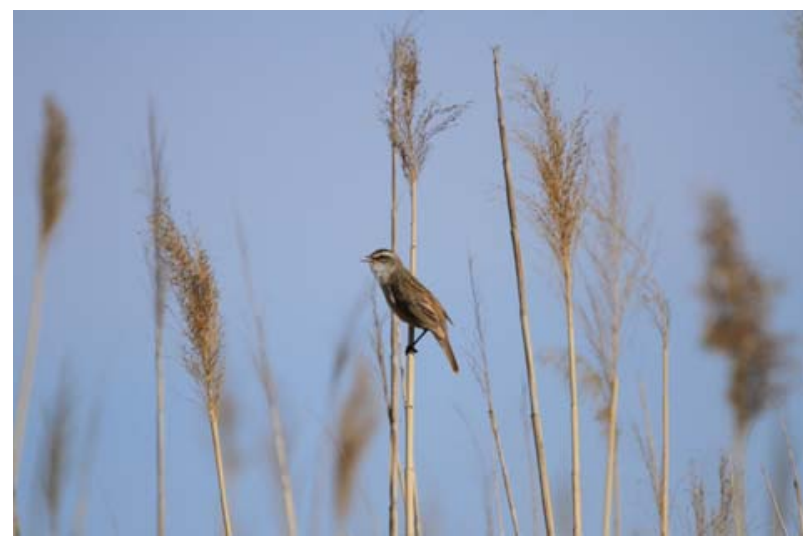

Fig. 1 A Moustached Warbler (Acrocephalus melanopogon) observed in Ulanbuy wetland, Urumqi, Xinjiang, on 22 April 2016 (photographed by XU Kangping)

\section{Morphological characteristics of Moustached Warbler}

Moustached Warbler, belonging to the genus of Acrocephalus and the family of Acrocephalidae, is a small Acrocephalus warbler with a length of 12-14 cm and a wing span of 58-62 $\mathrm{mm}$ (Svensson et al., 2010). Moustached Warbler has a striking face pattern with broad whitish supercilium and contrasting dark crown. In fresh plumage, the upperparts are rusty-brown with tinged reddish-brown, and the underparts are a clay color (Kennerley et al., 2010; Svensson et al., 2010; Ayé et al., 2012). In breeding plumage, it has olive-brown, rusty tinged upperparts with dark-brownish streaks on its back. Its head is darker than the back, with a darker stripe above the whitish supercilium; and the crown is rusty-grey with dark brown centers of the feathers. The upper tail is yellowish brown without mottling. The underparts are of white on the breast, flanks and under tail, and the underwings are white. Its primary projection is short $(<50 \%$ of the exposed tertial length), with a maximum of six feather tips and emarginations on primaries 3-5 (Fig. 1). The bill is essentially dark (with only a very small pale base to the lower mandible), strong and pointed with a very fine tip. The legs are lead-grey and the eyes are brownish. The sexes of Moustached Warbler are alike.

Moustached Warbler is rather similar to Sedge Warbler (Acrocephalus Schoenobaenus) in terms of the morphological characteristics (Fig. 2). Compared to Moustached Warbler, however, Sedge Warbler has a shorter primary projection and the supercilium is broad and white. Furthermore, the bill is entirely black, the legs are dark and the tails are more rounded and often cocked.

\section{Geographical distributions of Moustached Warbler}

Geographically, Moustached Warbler is mainly distributed in Central Asia, Middle East, Pakistan, and northwestern India (Ali and Ripley, 1997; Kennerley et al., 2010; Svensson et al., 2010). Moustached Warbler usually inhabits the reed beds of flooded lowland, in which Phragmites spp. are widely distributed and usually mixed with Typha spp., Scirpus spp. and Cladium spp. (Ali and Ripley, 1997; Wassink and Oreel, 2007; Ayé et al., 2012). Similarly, a narrow and long reed belt was distributed in Ulanbuy wetland, the site where Moustached Warbler was found in China. Vegetation coverage in this area is high, with the dominant species of Phragmites communis.

Moustached Warbler breeds widely but locally in the warm temperate regions from Northwest Africa and eastern Iberian Peninsula to eastern Kazakhstan (Ali and Ripley, 1997; Kennerley et al., 2010; Svensson et al., 2010; Ayé et al., 2012). Totally, three subspecies were recognized in the 
species of Moustached Warbler (Acrocephalus melanopogon) in the world, i.e., Acrocephalus melanopogon melanopogon distributed from southern Europe to Ukraine, western Turkey and Northwest Africa; Acrocephalus melanopogon mimicus distributed from eastern Turkey through southern Russia to Kazakhstan, Iran and Iraq; and Acrocephalus melanopogon albiventris distributed in south-eastern Ukraine and southwestern Russia (Gill and Donsker, 2015). According to the morphological characteristics (Wassink and Oreel, 2007; Kennerley et al., 2010) and geographical distributions of these three subspecies, we speculate that the Moustached Warbler observed in China would be Acrocephalus melanopogon mimicus.

In terms of the geographical distribution regions of Moustached Warbler, Kazakhstan is the nearest region to Xinjiang of China. In Kazakhstan, Moustached Warbler breeds in Volga-Ural region, Syrdarya valley, Tengiz-Korgalzhyn region and Balkhash-Alakol region (Wassink and Oreel, 2007). However, whether or not the Ulanbuy wetland is the breeding area of Moustached Warbler in China, future observations and verification are needed.

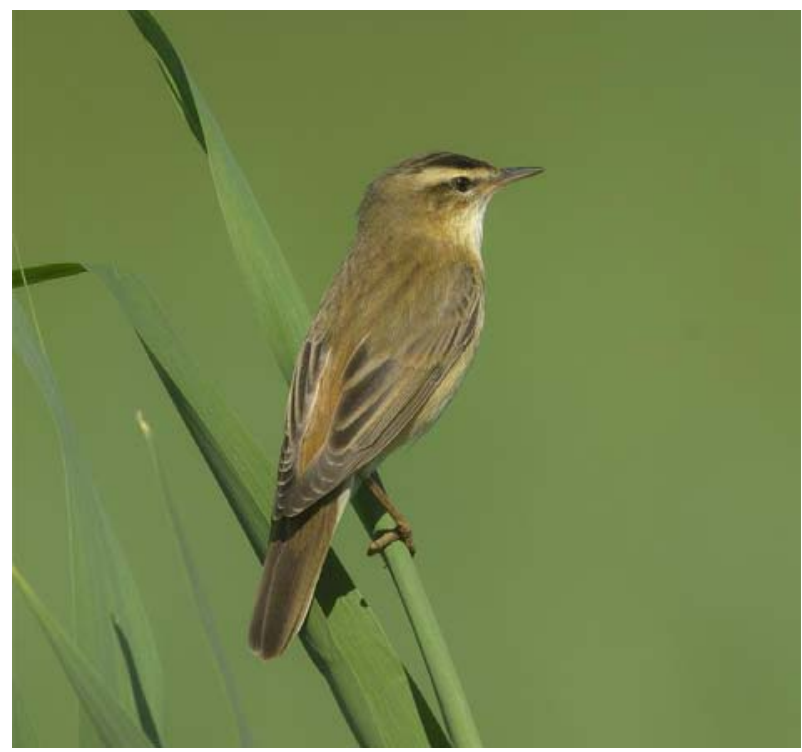

Fig. 2 A Sedge Warbler (Acrocephalus schoenobaenus) observed in Emin County, Xinjiang (photographed by WEN Zhimin)

\section{Song characteristics of Moustached Warbler}

As Moustached Warbler is a songbird, we recorded the songs of Moustached Warbler with eight replicates using a Sony PCM D-100 recorder on 18 May (2016), and generated the spectrograms using the Avisoft-SASLab software (Avisoft Bioacoustics, Germany). Spectrograms were generated using the following settings: sampling frequency of $22.05 \mathrm{kHz}$, sample size of 16 bits, FFT length of 256 points, a frame size of $100 \%$ and an overlap of $50 \%$ for hamming window, frequency resolution of $86 \mathrm{~Hz}$, and time resolution of $5.8 \mathrm{~ms}$.

Strophes were separated from each other by pauses $(>0.5 \mathrm{~s})$ and organized by elements. It should be pointed out that the element was defined as a continuous trace on a spectrogram, which was the smallest unit in measuring. For each strophe, we measured the duration of strophe, the maximum frequency of strophe, the minimum frequency of strophe, and the number of elements with strophe (Lindholm and Lindén, 2007). It should be mentioned that we only focused on the dominant component (with the maximum energy) in each element when measuring the frequency of strophes.

The songs of Moustached Warbler were often mixed with a series of whistles. Generally, 3 to 4 whistles were contained in one song and the whistles in each song did not exceed 20 (Fessl and Hoi, 1996; Kennerley et al., 2010). Furthermore, there were few occasional songs which were 
completely composed of whistles. The whistles in songs increased slightly in pitch and volume, with frequency range of $2-3 \mathrm{kHz}$ (Fig. 3). The main song was slightly faster with more high warbling notes (warbling part). The mean minimum frequency of strophe and the mean maximum frequency of strophe were $1.72( \pm 0.14)$ and $6.64( \pm 0.47) \mathrm{kHz}$, respectively (Table 1). Competition and attraction are two key functions in bird songs. The structures of songs are affected by both intra- and intersexual selection and may differ significantly from one type to another (Berglund et al., 1996; Catchpole and Slater, 2008; Byers and Kroodsma, 2009; Byers, 2011). For Moustached Warbler, the whistle part with simple structures at the beginning of the song conveys the information of competition between the same sexes, while the warbling part with complex structures at the end of the song conveys the information of courtship to the opposite sexes (Fessl and Hoi, 1996).

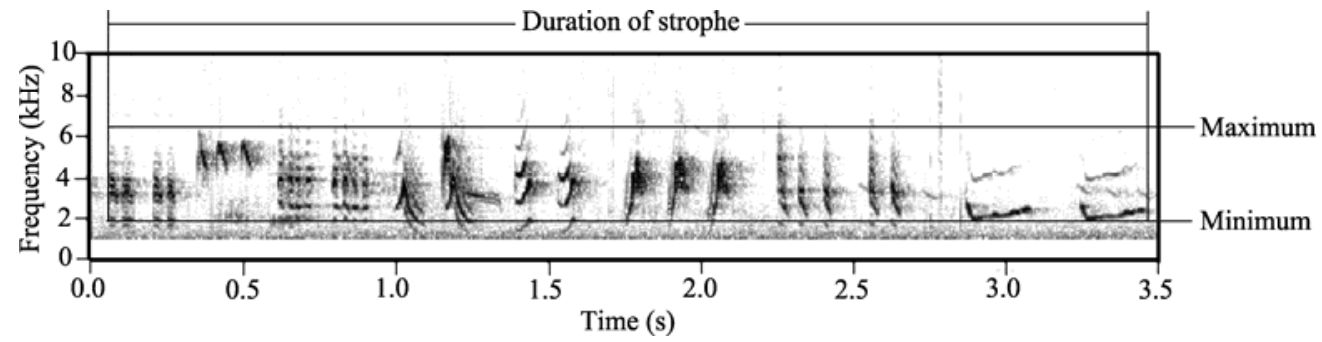

Fig. 3 Song strophes of Moustached Warbler (Acrocephalus melanopogon)

Table 1 Statistic parameters of song characteristics of Moustached Warbler (Acrocephalus melanopogon)

\begin{tabular}{ccccc}
\hline Sample & $\begin{array}{c}\text { Duration of strophe } \\
(\mathrm{s})\end{array}$ & $\begin{array}{c}\text { Maximum frequency of strophe } \\
(\mathrm{kHz})\end{array}$ & $\begin{array}{c}\text { Minimum frequency of strophe } \\
(\mathrm{kHz})\end{array}$ & \begin{tabular}{c} 
Number of elements \\
\hline 1
\end{tabular} \\
\hline 12.60 & 6.80 & 1.55 & 96 \\
2 & 4.53 & 6.28 & 1.72 & 36 \\
3 & 6.37 & 7.49 & 1.98 & 42 \\
4 & 31.50 & 7.14 & 1.72 & 202 \\
5 & 17.40 & 6.37 & 1.55 & 115 \\
6 & 5.21 & 6.11 & 1.80 & 40 \\
7 & 1.74 & 6.37 & 1.80 & 8 \\
8 & 6.48 & 6.54 & 1.63 & 56 \\
Mean & 10.73 & 6.64 & 1.72 & 74 \\
SD & 9.76 & 0.47 & 0.14 & 62 \\
\hline
\end{tabular}

Note: SD, standard deviation.

\section{Acknowledgements}

This study was supported by the Investigation of Terrestrial Wildlife Resources in the Zoogeographic Unit of North Slopes of the Tianshan Mountains, Xinjiang, China (XJLK2014009), the Second Wetland Resource Survey of Xinjiang Uygur Autonomous Region (XJLK2011008), and the National Key Research and Development Programme (2016YFC1200700). We are grateful to Anna YASKO, Askar ISABEKOV, Raffael AYÉ and LIU Yang for their help in identifying the Moustached Warbler and to WEN Zhimin for providing the photos of Sedge Warbler. Special thanks also to Dr. XIA Canwei for analyzing the song characteristics and to Paul HOLT for revising the English of this paper.

\section{References}

Ali S, Ripley S D. 1997. Handbook of the Birds of India and Pakistan: Together with Those of Bangladesh, Nepal, Sikkim, Bhutan and Sri Lanka: Volume 8: Warblers to Redstarts. Delhi: Oxford University Press, 114-116.

Ayé R, Schweizer M, Roth T. 2012. Birds of Central Asia: Kazakhstan, Turkmenistan, Uzbekistan, Kyrgyzstan, Tajikistan, Afghanistan. Princeton: Princeton University Press, 212-213. 
Berglund A, Bisazza A, Pilastro A. 1996. Armaments and ornaments: an evolutionary explanation of traits of dual utility. Biological Journal of the Linnean Society, 58(4): 385-399.

Byers B E, Kroodsma D E. 2009. Female mate choice and songbird song repertoires. Animal Behaviour, 77(1): $13-22$.

Byers B E. 2011. Birdsong, migration and sexual selection: a skeptical view. Animal Behaviour, 82(5): e1-e3.

Catchpole C K, Slater P J B. 2008. Bird Song: Biological Themes and Variations (2 ${ }^{\text {nd }}$ ed.). New York: Cambridge University Press, 171-201.

China Bird Report Eds. 2016. The CBR Checklist of Birds of China v4.0. [2016-03-13]. http://sf924d7bab545e307.jimcontent.com/download/version/1457969827/module/6330441156/name/\%E4\%B8\%AD\%E5\% $9 \mathrm{~B} \% \mathrm{BD} \% \mathrm{E} 9 \% \mathrm{~B} 8 \% 9 \mathrm{~F} \% \mathrm{E} 7 \% \mathrm{~B} 1 \% \mathrm{BB} \% \mathrm{E} 5 \% 90 \% 8 \mathrm{D} \% \mathrm{E} 5 \% \mathrm{BD} \% 95$ v4.0.pdf. (in Chinese)

Fessl B, Hoi H. 1996. The significance of a two part song in the moustached warbler (Acrocephalus melanopogon). Ethology Ecology \& Evolution, 8(3): 265-278.

Gill F B, Donsker D B. 2015. IOC World Bird List v5.4. [2015-10-14]. http://www.worldbirdnames.org.

Kennerley P, Pearson D, Small B. 2010. Reed and Bush Warblers. London: Christopher Helm, 72-75, $289-295$.

Lindholm A, Lindén A. 2007. Some notes on the distribution and songs of two Oriental Cuckoo taxa, Cuculus (saturatus) saturatus and Cuculus (saturatus) optatus. Forktail, 23: 12-16.

Ma M. 2011. A Checklist on the Distribution of the Birds in Xinjiang ( $2^{\text {nd }}$ ed.). Beijing: Science Press, 1-244. (in Chinese)

Sudilowskaja A M. 1936. The Birds of Kashgaria. Moscow: Academy of Sciences, USSR, 1-124. (In Russian)

Svensson L, Mullarney K, Zetterström D, et al. 2010. Collins Bird Guide: the Most Complete Field Guide to the Birds of Britain and Europe ( $2^{\text {nd }}$ ed.). London: HarperCollins, 290-291.

Wassink A, Oreel G J. 2007. The Birds of Kazakhstan. Texel: De Cocksdorp, 186.

Zheng G M. 2011. A Checklist on the Classification and Distribution of the Birds of China (2 ${ }^{\text {nd }}$ ed.). Beijing: Science Press, 1-456. (in Chinese) 